\title{
M2M Communication in Virtual Sensor Network for SHAAL
}

\author{
ZubairKhalid $^{a b}$, N. Fisal ${ }^{a}$, Rahat Ullah ${ }^{a b}$, HashimSafdar $^{a b}$, Wajaha Maqbool ${ }^{a}$, S.Zubair ${ }^{a}$ and A. S. Khan ${ }^{a}$ \\ ${ }^{a}$ UTM-MIMOS Center of Excellence, Faculty of Electrical Engineering, \\ Universiti Teknologi Malaysia, \\ 81310 UTM Johor Bahru, Johor, Malaysia. \\ ${ }^{b}$ Department of Electrical Engineering, \\ Federal Urdu University of Arts Science \& Technology, \\ G7/1-Islamabad, Pakistan.
}

*Corresponding author:engr.zubairkhalid@yahoo.com

\section{Article history}

Received XXXX

Received in revised form XXXX Accepted XXXX

\section{Graphical abstract}

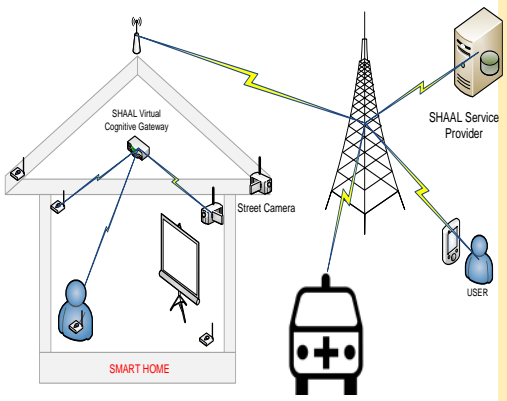

\begin{abstract}
Machine-to-Machine (M2M) communication has led to a new paradigm of Internet of Things (IoT). The future of M2M communication in smart home lies in the aggregation and allocation of resources and service provisioning of diverse applications using different radio technologies. M2M communication may operate on the virtual sensor network to provide independent applications running on heterogeneous network simultaneously. M2M is going to play a major role in the area of Smart Home and Ambient Assisted Living (SHAAL) providing assistance to the elderly people with smart sensors that monitor the home environment and provides aid health monitoring to human requiring medical assistance.

The current state of the art frameworks are dedicated to specific applications with the support of single radio network with limited service provisioning options. However, in order to fully exploit the resources in this paper we present a service provisioning framework realization of M2M in virtual sensor network for SHAAL, which allows independent parties to work together in a secure and reliable manner. In addition to this, the framework is designed to include benefits of Service Oriented Architecture (SOA) and Resource Oriented Architecture (ROA) along with the use of different low power, low data rate protocols. A middleware is used as a platform to link the underlying virtual networks with various applications. The network virtualization approach is adopted to design an efficient middleware framework that can effectively discover and manage the underlying network resources and provide services at home gateway. The framework will be used as the basis for the development of the SHAAL networked system.
\end{abstract}

Keywords: M2M Communications, SOA, Virtual Sensor Network, Middleware

\begin{abstract}
Abstrak
Kumunikqsi mesin-kepada-mesin (M2M) telah membawa kepada satu paradigm baru Jaringan Baranga (IOT). Masa depan komunikasi M2M salam rumah fintar terletak pada pengumpulan dan pengagihan sumber dan penyediaan perkhidmatan kepada pelbagaii aplikasi yang menggunakan teknologi radi yang berbeza. Komunikasii M2M boleh beroperasi pada rangkaian sensor maya untuk membolehkan aplikasi bebas berjalan serentak di rangkaian hetrogene. M2M akan memainkan peanan utama dalam bidang rumah pintar dan bautuan kehidpan. Rangka kerja terkini adalah khusus untuk aplikasi tertentu denga sokongan rangkaian radio tugagal dan pilihan peruntukan perkhidmatan yang terhad. Walaubagaimanapun, dalam usha untuk mengeksplaitasi sepenuhnya sumber-sumber yang ada dalam kertas ini, kami membentangkan rangaka kerja peruntukan perkhidmatan bagi merealisasikan M2M dalam rangkaian sensor maya untuk (SHAAL), yang membolehkan pihak-pihak bebeas untuk SHAAL, yang membolehkan pihak-pihak bebs untuk. Bekerja bersama-sama dengan cara yang selamat. Dan boleh dipercayai. Di samping itu rangka kerja ini diraka untuk meliputi faedha seni bira berorientasikan perkhidmatan (SOA) dan seni bina berorientasikan sumber (ROA) bersama-sama dengan pengguraan protokol berkuasa rendah dan berkadar data endha yang berbeza. Suatu perisian-tengah digunakan sebagai perantra untuk mengubungkan rangkaian maya asas dengan pelbagai aplikasi. Pendekatan virtualisasi rangkaian digunakan untuk mereka bentuk rangaka kerja perisian- tengah yang berkesan bagi menemui dan menguruskan sumber-sumber rangkaian asas dan menyediakan perkhidmatan di derbang rumah. Rangka kirja ini akan digunakan sebagai asas bagi pembengunan system rangkaian SHAAL. Keywords: M2M Communications, SHAAL, Virtual Sensor Network, Middleware
\end{abstract}

C) 2012 Penerbit UTM Press. All rights reserved. 